\title{
Corporate Governance Mechanisms: Their Strengths, Weaknesses and Complementarity
}

\author{
Jan Urban ${ }^{1, *}$ \\ ${ }^{1}$ Institute of Technology and Business in České Budějovice, Faculty of Corporate Strategy, Okružní \\ 517/10, 37001 České Budějovice, Czech Republic
}

\begin{abstract}
By corporate governance mechanisms we understand both market and non-market processes, including corporate rules and measures that tackle, internally and externally, two corporate governance problems, i.e. the vertical governance problem that arises between shareholders and managers, and the horizontal governance problem occurring between shareholders themselves. Efficient corporate governance mechanisms, aligning various stakeholder's interests, help to put the right managers in the right place, providing them at the same time with the right set of incentives and constraints. While some corporate governance mechanisms serving these goals, both internal and external from the corporation perspective, are more efficient in dealing with vertical corporate governance, other solve better horizontal governance issues. The main emphasis of the article is laid on the relative role and limits of market and non-market corporate governance mechanisms solving vertical governance problems as well their complementarity and substitution possibilities. Its method is mainly based on secondary analysis of case studies in corporate governance.
\end{abstract}

Key words: corporate governance, agency costs, public corporation, corporate performance

\section{Introduction}

Corporate governance refers to mechanisms of interests' alignment through which corporations are controlled and directed by their shareholders, other stakeholders (employees, creditors, investors, customers, suppliers etc.), as well as the public as a whole $[1,2]$. Without effective governance mechanisms, the principal-agent problem may arise, enabling the managements ("agents") to engage in "opportunistic behavior"2, detrimental to the enterprise's owners, stakeholders as well the economy as a whole $[3,4,5,6]$.

\footnotetext{
* Corresponding author: urban@mail.vstecb.cz

${ }^{2}$ Opportunistic behavior occurs where one party takes advantage of its superior knowledge, in order to further his/her interests, e.g. by failing to disclose such information to the other party $[5,7,8,9$, $10]$.
} 
The typical corporate governance problem has a both vertical and horizontal aspect [9, 11]. The vertical aspect of the problem is especially relevant in corporations with dispersed shares ownership. It arises between senior managers and shareholders and its focus is on keeping the senior management loyal to shareholders as well as competent enough for the goals of the firm's management.

The horizontal aspect of the corporate governance problem occurs between dominant and dispersed shareholders; its focus is on preventing the shifts in value from dispersed to dominant or controlling shareholders. It appears in countries/corporations, including the Czech Republic $[10,12,13]$, that fail to develop mechanisms that would effectively stop dominant stockholders' self-dealing. i.e. attempting to benefit from transactions that are being executed on the behalf of the corporation.

The two aspects of the corporate governance problem share one similar characteristic: in each the controlling agent may extract "rent" (private benefit) at the cost of remaining shareholders $[9,11,12]$. The way through which they can do so, however, differs and so do the mechanisms to minimize the scope of the problem. This article is mainly looking at the problem of vertical corporate governance (the shareholder-manager interests' alignment problem) and the relative efficiency of market and non-market mechanisms of its prevention.

The shareholder-manager interests' alignment problem may appear in two main forms which usually differ in terms of their visibility or transparency. The first concerns the possibility of diversion of firm's assets, the second managers' (in)competence [6, 14, 15].

As for assets' diversion, managers can divert value from the firm into their own hands either less transparently, e.g. by having the firm sell goods at low prices, buy at high prices (to and from entities that the managers control etc.) or, more transparently, e.g. by paying themselves (excessively) high salaries.

The other form of shareholder-manager interests' alignment problem, i.e. incompetence, concerns the fact that managers may not be up to running the firm in the first place. This may happen either because their selection was a mistake (which may have only appear with a delay), or because changed circumstances made the manager no longer suitable for the job $[14,16]$.

Mechanisms aligning the interests of shareholders and senior managers can be - from the perspective of the corporation - both market and non-market. The former cover mainly competitive markets of good, capital and labor (including managers), the latter are predominantly based on performance based management incentives and external corporate governance.

The firm's product, capital, managerial and labor markets, are often the most important mechanisms of corporate governance. Their function is based on their ability to punish lowperforming and reward well-performing organizations. If the firm, due to its bad management, cannot profitably sell its products, it sooner or later disappears from the market; if it, due to the same reason, cannot raise capital, it cannot grow, and if it cannot get and retain good managers and employees, it will waste its resources. Also, if its executives manage the firm poorly, they lose their market reputation; competitive markets distinguishing between performing and non-performing firms may thus also distinguish between performing and non-performing managers $[1,4,15]$.

The importance of markets as corporate governance mechanisms leads sometimes economists to underrate the importance of non-market governance instruments. The role of market mechanisms in corporate governance, though crucial, has, however, its limits. It is 
diminished mainly in markets with lower competition as well as in cases when they tend to act only from a longer term perspective.

\section{Data and Methods}

The analysis of corporate government mechanisms rests on economic, management and organization theory $[2,3,6,8,17,18]$ as well as data sources provided by case studies of specific corporate governance problems and issues [4, 5, 6, 14, 15].

The basic assumption of this analysis, supported by literature $[1,16,17]$ is that though efficient corporate governance helps in both putting the right manager in the right place and providing him with the right set of incentives and constraints, specific corporate governance mechanisms may, however, not be in the position to reduce both diversion and incompetence issues simultaneously. Some may affect one, some the other. Thus the issue of complementarity of market and non-market governance mechanisms arises.

\subsection{Market Mechanisms of Corporate Governance}

Markets may be good at some corporate governance tasks, but weak at others. They can, for example, be efficient at limiting the most alarming types of management incompetence, but less good at limiting diversion, especially if this represents a small part of the firm's total value. Also, markets tend to be imperfect mainly in terms of not obeying the principles of perfect competition, sometimes substantially so. If this is the case, instead of acting as a tight constraint, they often have their limits in terms of governance mechanisms.

\subsubsection{The case of imperfect managerial and labor markets}

The issue of market imperfection can be illustrated on the case of managerial and labor markets. It is true that managers usually want to be compensated and promoted, and thus try to act accordingly. If they do badly, they'll jeopardize their compensation and their future career prospects. But many senior managers are at the end of their careers: they aren't usually moving anywhere, except into retirement. Labor markets thus may be important in selecting the "right" people for these final positions, but less efficient thereafter: once "selected" for their final jobs, managers face labor market constraints that are weak. Furthermore, most of these senior managers at large firms are already very rich and more money may only motivate them weakly.

Employee labor markets can play their role within the labor-management dimension of corporate governance. A firm that treats employees badly, fails to motivate them or doesn't induce them to be productive will usually face labor market problems. Good and/or ambitious employees will leave, those less productive will stay. But even this labor market has its limits. The point is that in many countries external labor markets are not fully flexible.

Concerning the managerial and labor markets in general, the point here is not that these markets utterly fail to constrain managers, but that they are not perfect constraints. Eventually, if the firm applies poor personnel policy it will hit a limit in one or another of these markets. But it can, depending on its market setting, take some time. 


\subsubsection{Performance based executive compensation schemes}

One or two decades ago, performance compensation, especially incentives based on shares or share options, seemed a promising way to align senior manager's interests with that of shareholders, and thereby reduce the vertical corporate governance problem [19]. The theory was simple: managers who become equity owners have a higher motivation to raise the company financial performance. If managers get options to buy the company's stock and if their management of the firm induces stock price to rise, the manager's cash in options and make money. If their management of the firm doesn't induce its stock price to rise, then the managers' options are without value.

Incentive compensation certainly is an important instrument of corporate governance, but it too has its limits. First, for incentive compensation to be effective, the shares on which the options are written must be accurately priced. Second, with shareholders scattered and not themselves writing the incentive contract, the options may not fully motivate managers while they can successfully enrich them. Since the common options contracts seem to fall short of an ideal contract, there's good reason to think that the options actually used don't resolve the vertical governance problem as well as they could. They have typically been based on a general rise in the company's share price and not its performance compared to that of other (competing) firms.

Many analyses also conclude that incentive compensation works best in the long run, and its efficiency depends on the time-span. Over approximately a decade, managers at strongly performing companies do indeed earn much more than managers at weakly performing companies.

Another problem of the incentive compensation institution, not noted in the economic literature, is that even if the compensation is well attuned to firm's performance, senior managers, once they become rich, do not turn the firm over to a new crew of "hungry" managers. They instead continue, while wealthy, running the firm. For these people surely more money remains better than less money, but one can question how strongly incentive compensation motivates them. Its role thus might rather be to motivate managers seeking to be truly wealthy (those lower down in the firm's hierarchy), not those already there.

\subsection{Non-market corporate governance mechanisms}

Non-market corporate governance mechanisms cover mainly lawsuits, corporate information disclosure rules, intrinsic management motivation and external, i.e. social corporate governance instruments. Their role lies in their ability to work where markets cannot reach. In other words, while markets deal sometimes only with gross deviations, non-market corporate governance mechanisms can deal with subtler governance failures.

In those cases, non-market institutions can be more important than markets. That is, sometimes the non-market institutions are better, cheaper, and faster at governing the firm than the market constraints.

Second, the non-market corporate governance institutions can strengthen the market mechanisms. Good internal decision-making can make sure good managers come, stay, and perform and can thus facilitate the firm's adaptation to the markets' pressures. Good nonmarket governance institutions can thus become one of the bases for competition in all three markets. 


\subsubsection{Corporate lawsuits and corporate information disclosure rules}

Threat of corporate lawsuits, i.e. the possibility to sue company managers, represents often the main non-market corporate governance instrument. In most countries there are two broad ways for shareholders to sue managers: the breach of fiduciary duties (the duty of loyalty and the duty of care) and breach of securities law obligations [4].

Executives who divert company assets from the firm to themselves or their relatives (i.e. steal) violate typically the first of these duties, while managers who make the firm to sell its products at a lower price (compared with the market price) will typically violate the second of these duties. The latter case, breach of securities law obligations relates most basically to the company's quality of information disclosure, and can involve public enforcement actions as well as private lawsuits.

Unlike market restraints which are not likely to reduce insiders' opportunistic behavior strongly (since the value diverted from the company can be relatively low in relation to the size of the firm's assets and markets cannot work well if they don't know about the wrongdoing), law-based institutions, serving mainly as a deterrent, can be in these cases more efficient. They are, however, usually less efficient as a tool for solving the problem of managerial incompetency. The reason is that corporate courts often won't listen to complaints about managerial decision mistakes.

Corporate information disclosure rules, on the other hand, are usually better at tackling management failures since shareholders can see the bottom line results that managers produce. At the same time, however, they are often less efficient at handling diversion because, mainly in large firms, personal wealth can often be obtained without destroying the corporate bottom line.

\subsubsection{Intrinsic motivation of managers}

The economic theory usually does not cover the issue of managers' "internal" motivation. The fact, however, is that managers do not act solely for remuneration, but also for the satisfaction of "doing a good job", no matter how circumstantial this motivation can be. As professionals they want the firm to do well. They are often used to work for shareholders, and often do so even when the other institutional constraints are not tight. Or, managers who feel good about themselves if they introduce a new product or technology innovation, and make shareholders profit.

These notions of professionalism are softer and less well understood than the other institutions, but that doesn't mean that they are absent, or unimportant.

As far as intrinsic motivation theory is concerned, several scientifically proven as well as and some alternative motivation theories were created. Miner, 2005 summarizes that managers motivation can be among other aspects characterized by attitude towards authority, need for competition, need for power, need for affirmation, need for different and differential status, wish for doing routine managerial duties etc. From these theories is clear that only material motivation is not quite appropriate and not enough for managers (researcher also found weak, neutral or even negative correlation between managerial compensations and managerial work efficiency, other also found that in dominantly intellectual duties/work the best motivation is psychological (intrinsic) one, and for dominantly physical duties/work the best motivation is material (extrinsic) one. Therefore, according to those results dominant physical work should be rewarded by material 
strategies and dominant intellectual work should use more psychological/intrinsic strategies - what is quite opposite the practice in corporate world.

Furthermore, more general human motivation theories have some important managerial implication e.g. Maslow's need hierarchy, Alferder theory of three stages, theories of achievement motivation (McClelland and Atkins), two factor theories (Herzberg), theory of role motivation (Miner), theory of justice in social exchange (Adams), integral process models of motivation, self-determination motivation theories, flow theories, also old wellknown and (mis)used punishment-reward theory. Though these theories can give important insights into management intrinsic motivation and are therefore important for the application of practical management motivation measures, their analysis goes beyond the scope of this article focused on alternative corporate governance institutions.

\subsubsection{External corporate governance: issues of corporate social legitimacy}

Corporate governance can have another, external dimension [16]. Being neither horizontal, nor vertical, nor necessarily governing the relationships among owners and managers, this dimension is of governing the firm in a way that it is legitimate in its society.

This legitimacy dimension is mainly determined by the outsiders: the society demands that the firm structure its governing institutions in a way that leads to implementing into its objectives some of the goals of public policy. Issues of legitimacy can be, however, extended in further directions. For example, one might view the problem of corporate governance in organizational terms, as how to motivate a team, how to keep it flexible but effective, etc.

This dimension is less pronounced in some countries and more in others. It is usually absent in academic economic literature though analyzed in management literature. An example is the role of employees in corporate governance. They are typically seen as inputs or suppliers that managers transform into sales and profits. Even though employees have to be paid well and have to think well of their work/corporate environment, this is not usually seen as a corporate governance issue (in terms of aligning the interests of company stakeholders). In some countries, however, where social considerations and the role of employees have much more impact, their role tends to be formalized, e.g. in the form of Germany inspired codetermination, in which employees end up inside the boardroom. Generally speaking, the role of employees in decision making can be rather technical onewhere to employee is given the freedom/duty to take part in technical improvements or strategic one, when the employees have the authority to take part in decisions concerning important corporate management topics including investment directions and distribution of earned profit.

The external dimension of corporate governance focuses less on relationships between shareholders and managers or among shareholders. It could, however, have a "legitimacy" angle, and it could have an "efficiency" angle, as such a focus might yield greater productivity and more utility for those inside the organization.

This issue of corporate governance and legitimacy can also be seen more abstractly: how, can one organize a business entity that survives politically and socially and how have corporate institutions adapted to be legitimate in society? This kind of inquiry gets so far little attention in the academic literature, although it covers important issues like which institutions are legitimate, which ones don't attract negative attention from the society, or 
which ones manage to resist outside incursions better than others even if they turned out to be less effective in another (economic) dimensions.

The external dimension of corporate governance reflects the fact that business entity is also social entity which can also improve the life of employees by integrating them in different levels of decision making (not only in technical/operational sense, but also in strategical/political sense where it is possible) in order to improve the vitality of the company (efficacy and making money not only for „company“ but also for employees and their interests what can have huge positive results in overall motivation and corporate social legitimacy sense).

\section{Recommendations and Suggestions for Practice}

As we have seen, various (imperfect) corporate governance institutions can play the role of complements and/or substitutes. Though each of them can affect the alignment of managers and shareholders' interests (some primarily in decreasing the probability of insider diversions of value, and others in increasing the quality of management), in most cases they can substitute and complement each other. In these cases, their overall efficiency increases $[1,11]$.

Substitution is mainly effective if one institution becomes too costly, and the demand for the other corporate governance institutions rises. For example, competitive product markets confine managerial discretion (fierce competition can sharply lower corporate profitability if the managers' fail to take optimal decisions), and in that sense serve as a substitute for the other vertical governance institutions. Furthermore, lower profits usually lower the firm's stock price and make the incentive compensation less remunerative, and signal takeover entrepreneurs that a new opportunity. Thus, in markets and/or countries with historically strong product market competition firms can prosper without really strong governance constraints on managers because product market competition keeps managers working effectively.

Efficient corporate governance has also a positive spill-over effect. If markets are competitive, but all incumbent managers not performing properly, improving one corporate governance institution or another in one of the competitors, e.g. introducing incentive compensation or nominating a more dynamic board, can lead to reaction of the other competing firms as well. They can react by innovating but also by improving their own internal corporate governance systems, with better boards, better compensation, etc.

Similar principles concern the complementarity of institutions. Better information, for example, leads investors to price securities more accurately. It can, however, also motivate managers who feel ill-at-ease to see their shares price decline to make the value of those shares rise. Boards that got better feed-back (of declining shares prices) can be more inclined to take the action that might be needed, e.g. design better compensation plans or foster the professionalism of managers. Takeover entrepreneurs might also be inclined to act.

The topic of corporate governance is relevant. Stockholders are demanding improved governance of companies by strengthening the responsibilities and competencies of directors and managers and more responsive shareholder's relations. Companies with diffused ownership often suffer from the fact that the stockholders' agenda - maximizing profits/shareholder value - can be at odds with agendas of their managers. In this setting, aligning both parties' interests become the goal of institutions of corporate governance. The 
aim of these institutions, i.e. rules and mechanisms, is to tie managers to the interests of stockholders.

\section{Conclusion}

The stockholder-manager alignment problem appears in two main forms. The first concerns diversion, the second competence. Managers can divert value from the firm into their own hands: they can have the firm transfer funds to their own bank accounts (or a relative's), or have the firm sell goods at low prices to (or buy at high prices from) entities that the managers control. More transparently, they can pay themselves (excessively) high salaries. The other form concerns the fact that managers may not be up to running the firm, either because one or another manager never was up to the task (their selection was a mistake) or more plausibly because changed circumstances made the manager no longer right for his company.

Well-functioning corporate governance institutions put the right manager in the right place and give that manager the right set of incentives and constraints. This goal, however, hides a couple of issues. The first is that each specific corporate governance institution does not uniformly reduce both. Some affect one, some affect the other. Both problems, however, bring costs to shareholders.

Market and non-market corporate governance mechanisms, can thus be regarded as specialized: they can play the role of complements and/or substitutes. Lawsuits, for example, compared with markets, are more effective in tackling conflicts of interest while markets and other close to market mechanisms, e.g. managements' incentive instruments, are better suited to lead managers toward pro-shareholder decision-making and/or reduce the problems of management's incompetence.

Though each of these mechanisms can affect the alignment of managers and shareholders' interests (some primarily in decreasing the probability of insider diversions of value, and others in increasing the quality of management), in most cases they can substitute and complement each other. In these cases, their overall efficiency increases.

\section{References}

1. N. Kang, Analysing 'System Change': The Role of Institutional Complementarity in Corporate Governance. International Centre for Corporate Social Responsibility Nottingham University Business School Nottingham University, Research Paper Series, (43-2006), (2006)

2. R. Adams, B. E. Hermalin, M. S. Weisbach, The Role of Boards of Directors in Corporate Governance: A conceptual Framework and Survey. Journal of Economic Literature, 48(1), 58-107, (2008)

3. R. V. Aguilera, G. Jackson, Comparative and International Corporate Governance. The Academy of Management Annals, 4(1), 485-556, (2010)

4. B. J. Bushee, M. E. Carter, J. J. Gerakos, Institutional Investor Preferences for Corporate Governance Mechanisms. Journal of Management Accounting Research: Fall 2014, 26(2), 123-149, (2014)

5. G. Ferrarini, N. Moloney, Executive Remuneration in the EU: The Context for Reform. Law Working Paper [online], (32/2005), Available at: 
https://ecgi.global/sites/default/files/working_papers/documents/SSRN-id715862.pdf (2005)

6. J. P. Hawley, S. J. Kamath, A. T. Williams, Corporate Governance Failures: The Role of Institutional Investors in the Global Financial Crisis. University of Pennsylvania Press, (2011)

7. A. L. Friedman, S. Miles, Stakeholders Theory and Practice. OUP Oxford, (2006)

8. M. G. Gentile, Corporate Governance and Accountability: What Do We Know and What Do We Teach Future Business Leaders? The Aspen Institute Business \& Society Program, (2011)

9. N. Ozkan, Do corporate governance mechanisms influence CEO compensation? An empirical investigation of UK companies. Journal of Multinational Financial Management, 17(5), 349-364, (2007)

10. M. J. Roe, Political Determinants of Corporate Governance: Political Context, Corporate Impact. New York: Oxford University Press, (2006)

11. J. B. Miner, Organizational Behavior 1: Essential Theories of Motivation and Leadership. Routledge, (2015)

12. M. J. Roe, The institutions of corporate governance. Harvard Law and Economics Discussion Paper, (488), (2004)

13. M. Singh et al., Agency costs, ownership structure and corporate governance mechanisms. Journal of Banking \& Finance, 27(5), 793-816, (2003)

14. Z. Caha, J. Urban, Etické ř́zení organizace: Od etického kodexu k etickému ř́zení. RAM-Verlag, (2017)

15. P. C. Fiss, Institutions and Corporate Governance [online]. Available at: https://poseidon01.ssrn.com/delivery.php?ID $=47000211800510106911803009609110$ $\underline{5092096075037082045007068102004085117001006095014029013055021115109098}$ $\underline{1010840930250110860810210550580360760480831270311110310901070650060170}$ 9102308902601211208601408906608007207812500502611809110311608906710006 4081098\&EXT=pdf (2007)

16. C. M. Daily et al, Corporate Governance: Decades of Dialogue and Data. Academy of Management Review, 28(3), (2013)

17. Z. Caha, M. Vokoun, The Impact of the Presence of a Code Of Ethics on the Economic Prosperity of a Company. Innovation Management, Entrepreneurship and Sustainability 2017, 72-78, (2017)

18. M. Hilb, New Corporate Governance: Successful Board Management Tools. SpringerVerlag berlin Heidelberg, (2012)

19. Z. Caha, Central Europe: Ethical Overlaps of Environmental and Economic Interests in Coming Years. Science and Engineering Ethics, 24(6), 1801-1807, (2017) 